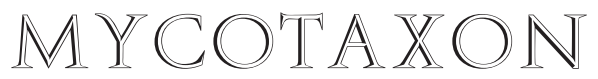

Volume 110, pp. 81-87 October-December 2009

\title{
AFLP characterization in pathogenic and coprophilous fungi
}

\author{
Isabel E. Cinto ${ }^{1 *}$, Alexandra M. Gottlieb ${ }^{2}$, Marcela Gally $^{3}$, \\ Maria E. Ranalli ${ }^{1}$ \& Araceli M. Ramos ${ }^{1}$ \\ *icinto@bg.fcen.uba.ar \\ ${ }^{1}$ Lab 9, Departamento Biodiversidad y Biología Experimental \\ Facultad de Cs. Exactas y Naturales, Universidad de Buenos Aires \\ Int. Güiraldes 2620 - C1428EHA - Buenos Aires - Argentina \\ ${ }^{2}$ LACyE, Departamento Ecología Genética y Evolución \\ Facultad de Cs. Exactas y Naturales, Universidad de Buenos Aires \\ Int. Güiraldes 2620 - C1428EHA - Buenos Aires - Argentina \\ ${ }^{3}$ Cátedra de Fitopatología, Facultad de Agronomía, Universidad de Buenos Aires \\ Av. San Martín 4453 - C1417DSE - Buenos Aires - Argentina
}

\begin{abstract}
The objective of this study was to ascertain the usefulness of the AFLP technique in assessing genetic diversity among 47 strains belonging to three Ascomycota genera and as a tool for solving taxonomic problems in related morphological species. Four MseI +1 primers were assayed in combination with two EcoRI +2 and four EcoRI +3 primers. In the present study both +2 and +3 EcoRI primers were informative, but EcoRI +2 produced profiles with high complexity. The addition of the extra selective nucleotide reduced the complexity of the banding patterns generating easily readable patterns to evaluate genetic diversity within and among species. Of the three ascomycetous genera assessed in this study, Colletotrichum (Glomerellaceae) presented the highest proportion of polymorphic AFLP loci, followed in order by Iodophanus (Pezizaceae) and Saccobolus (Ascobolaceae).
\end{abstract}

Key words - ascomycetes, genetic characterization, molecular markers, taxonomy

\section{Introduction}

Morphological and biochemical characterization of microscopic fungi have usually led to uncertainties in identification when dealing with closely related species or nearly clonal fungal isolates (van Brummelen 1967, Kimbrough et al. 1969, Ramos et al. 2000, Cinto et al. 2007, among others). Molecular markers constitute the current choice to evaluate genetic diversity and to obtain diagnostic characters as an aid for species level identification. For instance, the Amplified Fragment Length Polymorphism method (AFLP, Vos et al. 1995) 
is a DNA-based fingerprinting technique frequently used in a diverse array of organisms owing to the generation of high resolution markers, its relative technical simplicity, and because it requires no prior sequence information on the organism under scrutiny (Briad et al. 2002, Gottlieb et al. 2005, Roa et al. 1997, Zeller et al. 2000).

In the present study, we applied AFLP methodology to several filamentous fungal species representing ecologically diverse Ascomycota genera in order to investigate the efficiency of these molecular markers to assess genetic diversity and as a tool for solving taxonomic problems in closely related morphological species. The ascomycetes employed here involved the morphospecies Colletotrichum truncatum (Schwein) Andrus \& W. Moore 1935, Iodophanus carneus (Pers.) Korf 1967, I. testaceus (Moug.) Korf 1967, Saccobolus verrucisporus Brumm. 1967 and S. versicolor (P. Karst) P. Karst. 1885. During sexual reproduction these fungi develop haploid spores within an ascus and ascospores that generate a haploid mycelia after germination. In addition, these three genera are found on different substrates. Iodophanus and Saccobolus are mostly obligate coprophilous fungi. Within these genera, species delimitation is cumbersome due to extensive overlapping in morphological, cytological and developmental features. In contrast, Colletotrichum truncatum is the most common pathogen associated with soybean anthracnose (Armstrong-Cho \& Banniza 2006). Although more than 50\% of cultivated surface in Argentina is designated for soybean production, the genetic variability of this crucial pathogen has not been explored previously.

\section{Material and methods}

\section{Fungal strains}

Isolation and maintenance of haploid mycelia (monosporic derived strains) of Iodophanus and Saccobolus species followed procedures set forth by Gamundí \& Ranalli (1964). For this purpose, production of mature sexual spore-bearing structures (apothecia) was induced by placing cow and horse dung from different geographical locations into moist chambers (humid filter paper in Petri dishes).

Isolates of the asexual pathogen Colletotrichum truncatum were obtained from stem and pod lesions in symptomatic soybean plants (Glycine max (L.) Merr.) from different geographical locations, using the procedure of Levin et al. (2007).

The selected fungal strains are deposited at the Herbarium and Culture Collection of the Departamento de Biodiversidad, Facultad de Ciencias Exactas y Naturales, Universidad de Buenos Aires (BAFC). TABLE 1 indicates the geographic origin of each strain.

\section{DNA extraction}

Actively growing mycelia obtained according to Ramos et al. (2000) were ground in liquid nitrogen. Genomic DNA was extracted following Gottlieb \& Lichtwardt (2001). Quality control and quantification of genomic DNA was carried out by agarose gel $(0.8 \%$ 
TABLE 1. List of Argentine fungal strains employed in this survey, their geographical location and BAFC number.

\begin{tabular}{|c|c|c|}
\hline Species & LOCALITY & STRAINS TESTED ${ }^{*}$ \\
\hline C. truncatum & Gadeken, SF, Arg. & C1 (3093) \\
\hline C. truncatum & Cerro Azul, SF, Arg. & C2 (3094) \\
\hline C. truncatum & Armstrong, SF, Arg. & C4 (3096), C5 (3097), C6 (3098) \\
\hline C. truncatum & Lobos, $\mathrm{CH}$, Arg. & C8 (3100), C9 (3101), C10 (3102) \\
\hline C. truncatum & Salto, BA, Arg. & C14 (3396) \\
\hline C. truncatum & Las Lajitas, SA, Arg. & C15 (3397) \\
\hline C. truncatum & Piamonte, SF, Arg. & C26 (3398) \\
\hline C. truncatum & Otamendi, CO, Arg. & C24 (3399) \\
\hline C. truncatum & Las Varillas, SF, Arg. & C25 (3400) \\
\hline C. truncatum & Chivilcoy, BA. Arg. & C27 (3401) \\
\hline I. carneus & Hernández, ER, Arg. & TJ 1 (2970); TJ2 (3016); TJ3 (3017); TJ7 (3018); TJ10 (3019) \\
\hline I. carneus & Gualeguaychú, ER. Arg. & $\begin{array}{l}\text { ER1 (2965), ER2 (2966) ER12 (2967) ER14 (2968), } \\
\text { ER15 (2969) }\end{array}$ \\
\hline I. carneus & Agronomía, CABA, Arg. & $\begin{array}{l}\text { ICA1 (3414), ICA2 (3415), ICA3 (3416), ICA4 (3417), } \\
\text { ICA5 (3418) }\end{array}$ \\
\hline I. testaceus & Núñez, CABA, Arg. & IT 1 (3025), IT4 (3026), IT7 (3027), IT8 (3028) IT10 (3029) \\
\hline S. verrucisporus & Gualeguaychú, ER. Arg. & M3 (3402), M8 (3403), M10 (3404), M14 (3405) \\
\hline S. versicolor & Gualeguaychú, ER. Arg. & M4 (3406), M7 (3407), M11 (3408), M13 (3409) \\
\hline S. verrucisporus & Gob.Castro, ER. Arg. & M9 (3410), M12 (3411), M18 (3412), M19 (3413) \\
\hline
\end{tabular}

"Numbers in brackets correspond to the BAFC culture number (see Materials and Methods).

ER: Entre Ríos Province; CABA: Ciudad Autónoma de Buenos Aires; SF: Santa Fe Province; CH: Chaco

Province; BA: Buenos Aires Province; SA: Salta Province; CO: Córdoba Province; Arg.: Argentina.

w/v) electrophoresis and comparison with a DNA molecular-size standard (Lambda EcoRI/HindIII, Promega Corp.). Gels containing ethidium bromide were photographed under UV light.

\section{AFLP methodology}

AFLP analysis was carried out on 250 ng of genomic DNA using the AFLP ${ }^{\circledR}$ Analysis System for Microorganisms Primer Kit (Invitrogen) as described in the instructions manual with minor modifications (Gottlieb et al. 2005). Selected primers were combined as in TABLE 2. PCR amplifications were performed in a TECHNE PROGENE thermal cycler.

Polyacrylamide gel electrophoresis procedures followed Gottlieb et al. (2005). A 30-330 bp AFLP DNA Ladder (Invitrogen) size marker was included twice in each electrophoresis run. Thus, the size of AFLP bands scored ranged from 90 to $330 \mathrm{bp}$. AFLP bands were visualized using the SILVER SEQUENCE ${ }^{\mathrm{TM}}$ DNA Sequencing System (Promega). Air-dried gels were digitalized and visually analyzed using Adobe Photoshop TM (Adobe Systems, Mountain View, Ca, USA). 


\section{Data analysis}

Each AFLP band, regardless of its relative intensity, was considered as a dominant allele at a unique locus. The data were coded as either present (1) or absent (0). In some cases, fragments were scored as missing data because character states could not be interpreted unambiguously. Monomorphic bands (bands present in all individuals of a species) were discriminated within each species and across the entire data set. The percentage of polymorphic loci ( $\mathrm{P}=$ number of polymorphic loci/ number of loci analyzed) for each primer combination was calculated.

\section{Results and discussion}

In this study, a total of 46 ascomycetous fungal isolates were surveyed with the AFLP methodology employing ten selective primer combinations, as shown in TABLE 2. As a result, the number of reliable bands scored varied from 26 to more than 100, depending on the primer pair combination used.

For Colletotrichum truncatum eight selective primer combinations were tested, among which three rendered highly complex profiles and were not further analyzed (not shown). The remaining five primer combinations showed high P-values of $81.3-92 \%$. For Iodophanus carneus and I. testaceus, eight AFLP primer combinations were assayed that rendered P-values of $11-81 \%$. Saccobolus verrucisporus and S. versicolor yielded the lowest P-value range, $8.3-13 \%$.

Comparing results for the first three primer pairs of TABLE 2 it was evident that $C$. truncatum exhibited the highest proportion of polymorphic AFLP loci, followed in order by Iodophanus species and Saccobolus species. Our results are not surprising since C. truncatum is a highly virulent pathogen and, as such, natural populations are expected to preserve genetic variation.

In regard to the coprophilous fungi, the Iodophanus species generally showed more polymorphic bans than Saccobolus species (TABLE 2). This might be associated with the fact that Iodophanus species develop more variable sexual structures than those produced by Saccobolus (Cinto in prep.). Nevertheless, these differences are intriguing since both genera have homothallic life cycles and share the same kind of particular habitat. One major problem regarding identification of microscopic ascomycetes is that dimensions of morphological characters usually overlap. In addition, among other abiotic factors culture conditions and the quantity and quality of light, , would considerably influence ascocarp, ascospore, and ascus sizes (Cinto et al. 2007).

The range of total bands detected herein for Colletotrichum is within the range obtained by previous studies using less restrictive combinations (EcoRI +2 and MseI+1) on Colletotrichum from alfalfa (44-66) and Colletotrichum acutatum (90-105) (James et al. 2003, O'Neill et al. 1997). Similarly, the range of total bands detected for Didymella bryoniae (40-86) and Ophiosphaerella agrostis 
TABLE 2. Total number of AFLP bands, polymorphic and monomorphic bands detected for each selective primer combination in each fungal group assayed and calculated percentage of polymorphic loci (P\%).

\begin{tabular}{|c|c|c|c|c|c|}
\hline $\begin{array}{l}\text { PRIMER } \\
\text { COMBINATION }\end{array}$ & $\begin{array}{l}\text { FUNGAL } \\
\text { GROUP }\end{array}$ & $\begin{array}{l}\text { TOTAL } N^{\circ} \\
\text { OF BANDS }\end{array}$ & $\begin{array}{c}\text { POLYMORPHIC } \\
\text { BANDS }\end{array}$ & $\begin{array}{c}\text { MONOMORPHIC } \\
\text { BANDS }\end{array}$ & $\mathrm{P} \%$ \\
\hline \multirow{3}{*}{$\mathrm{M}+\mathrm{G} / \mathrm{E}+\mathrm{ACG}$} & $\mathrm{C}$ & 60 & 55 & 5 & 91.66 \\
\hline & I & 38 & 25 & 13 & 65.79 \\
\hline & $\mathrm{S}$ & 45 & 6 & 45 & 13.33 \\
\hline \multirow{3}{*}{$\mathrm{M}+\mathrm{C} / \mathrm{E}+\mathrm{AAG}$} & $\mathrm{C}$ & 103 & 95 & 8 & 92.23 \\
\hline & I & 59 & 41 & 18 & 69.5 \\
\hline & $\mathrm{S}$ & 60 & 5 & 55 & 8.33 \\
\hline \multirow{3}{*}{$\mathrm{M}+\mathrm{T} / \mathrm{E}+\mathrm{ACG}$} & $\mathrm{C}$ & 60 & 55 & 5 & 91.67 \\
\hline & I & 26 & 14 & 12 & 53.85 \\
\hline & $\mathrm{S}$ & 53 & 6 & 47 & 11.32 \\
\hline \multirow{3}{*}{$\mathrm{M}+\mathrm{A} / \mathrm{E}+\mathrm{AC}$} & $\mathrm{C}$ & +120 & $\#$ & \# & \# \\
\hline & I & 80 & 9 & 71 & 11.25 \\
\hline & $S$ & 95 & 8 & 87 & 8.42 \\
\hline \multirow{3}{*}{$\mathrm{M}+\mathrm{C} / \mathrm{E}+\mathrm{AA}$} & $\mathrm{C}$ & +120 & $\#$ & $\#$ & $\#$ \\
\hline & I & 89 & 11 & 78 & 12.36 \\
\hline & $\mathrm{S}$ & 79 & 7 & 72 & 8.86 \\
\hline \multirow{3}{*}{$\mathrm{M}+\mathrm{A} / \mathrm{E}+\mathrm{AA}$} & C & +120 & $\#$ & \# & $\#$ \\
\hline & I & $*$ & * & * & $*$ \\
\hline & $S$ & 90 & 7 & 83 & 8.4 \\
\hline \multirow{3}{*}{$\mathrm{M}+\mathrm{A} / \mathrm{E}+\mathrm{ACG}$} & $\mathrm{C}$ & 70 & 64 & 6 & 91.4 \\
\hline & I & 42 & 29 & 13 & 69.05 \\
\hline & $\mathrm{S}$ & * & * & * & * \\
\hline \multirow{3}{*}{$\mathrm{M}+\mathrm{C} / \mathrm{E}+\mathrm{ACC}$} & $\mathrm{C}$ & 75 & 67 & 8 & 89.3 \\
\hline & I & * & * & * & $*$ \\
\hline & $\mathrm{S}$ & 50 & 5 & 45 & 10 \\
\hline \multirow{3}{*}{$\mathrm{M}+\mathrm{A} / \mathrm{E}+\mathrm{AAC}$} & $\mathrm{C}$ & $\cdots \cdots$ & $\cdots * \cdots$ & $\cdots *$ & $\ldots \ldots$ \\
\hline & I & 55 & 45 & 10 & 81.82 \\
\hline & $\mathrm{S}$ & * & $*$ & * & * \\
\hline \multirow{3}{*}{$\mathrm{M}+\mathrm{T} / \mathrm{E}+\mathrm{AAC}$} & $\mathrm{C}$ & $*$ & $\cdots *$ & $\cdots$ & $*$ \\
\hline & I & 58 & 35 & 23 & 60.34 \\
\hline & $\mathrm{S}$ & * & * & * & * \\
\hline
\end{tabular}

$\mathrm{C}=$ Colletotrichum truncatum $; \mathrm{I}=$ Iodophanus carneus and I. testaceus; $\mathrm{S}=$ Saccobolus versicolor and S. verrucisporus; ${ }^{*}=$ not readable due to banding pattern complexity; ${ }^{*}=$ not tested; $\mathrm{E}=\mathrm{EcoRI}$; $\mathrm{M}=$ MseI.

(40-76) is within the range estimated here for Iodophanus and Saccobolus (Kothera et al. 2003, Cámara et al. 2000). In contrast, and as mentioned above, our results for the non-pathogenic fungi, Iodophanus and Saccobolus, disagree with results from other studies. In this way the use of AFLP adaptors with three selective bases not only reduced, as expected, the complexity of the banding 


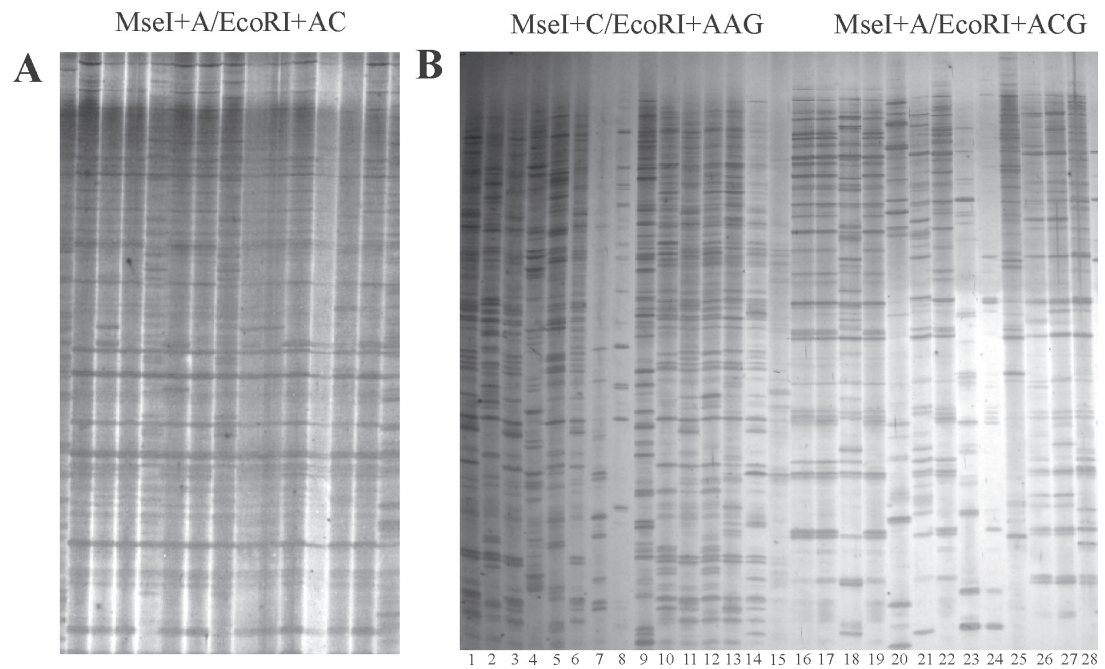

Plate 1. Section of AFLP showing amplification of DNA. A) Iodophanus carneus, M+A/E+AC;

B) Colletotrichum truncatum, $\mathrm{M}+\mathrm{C} / \mathrm{E}+\mathrm{AAG}$ (lanes 1-14) and $\mathrm{M}+\mathrm{A} / \mathrm{E}+\mathrm{ACG}$ (lane 15-28)

patterns, it also improved the detection of polymorphic bands (Plate 1, TABLE 2).

In the present study both +2 and +3 EcoRI primers were informative, but EcoRI +2 produced profiles with high complexity. The addition of the extra selective nucleotide reduced the complexity of the banding patterns generating easily readable patterns to evaluate genetic diversity within and among species. This protocol in which the number of selective nucleotide was tested allows the AFLP procedure to be extended into other Ascomycota (fungi) species.

Isolates identified as $S$. versicolor based on morphological characters shared almost $90 \%$ of AFLP bands with S. verrucisporus in all primer combinations tested. In this way, isolates previously identified as $S$. versicolor could represent an intraspecific variant of $S$. verrucisporus. A higher number of isolates will need to be assessed in order to resolve this relationship.

The present work involved a limited number of ascomycetous species and strains; at this time, more exhaustive studies are being conducted to evaluate the genetic variability of these particular fungi.

\section{Acknowledgments}

This study was supported by a grant from Consejo Nacional de Investigaciones Científicas y Técnicas (CONICET) and University of Buenos Aires, Argentina. We thank Dr. Leandro Papinutti, Dr. James Kimbrough and Dr. Lina Bettucci for the critical review of the manuscript. 


\section{Literature cited}

Armstrong-Cho CL, Banniza S. 2006. Glomerella truncata sp. nov., the teleomorph of Colletotrichum truncatum. Mycol. Res. 110: 951-956.

Briard M, Le Clerc V, Grzebelus LD, Senalik D, Simon PW. 2000. Modified protocols for rapid carrot genomic DNA extraction and AFLP ${ }^{\mathrm{TM}}$ analysis using silver stain or radioisotopes. Pl. Molec. Biol. Rep. 18: 235-241.

Brummelen J van. 1967. A world-monograph of the genera Ascobolus and Saccobolus (Ascomycetes, Pezizales). Persoonia Suppl. 1: 1-260.

Cámara MP, O’Neill NR, van Berkum P, Dernoeden PH, Palmer M. 2000. Ophiosphaerella agrostis sp. nov. and its relationship to other species of Ophiosphaerella. Mycologia 92: 317-325.

Cinto IE, Dokmetzian DA, Ranalli ME. 2007. Iodophanus carneus and I. testaceus (Ascomycota, Pezizales) Independent taxonomic identity or synonymy? A study of their morphology and isozymes. Bol. Soc. Argent. Bot. 42: 181-187.

Gamundí IJ, Ranalli ME. 1964. Estudio sistemático y biológico de las Ascoboláceas de Argentina I. Nova Hedwigia 7: 517-533.

Gottlieb AM, Lichtwardt RW. 2001. Molecular variation within and among species of Harpellales. Mycologia 93: 65-80.

Gottlieb AM, Giberti GC, Poggio L. 2005. Molecular analyses of the genus Ilex (Aquifoliaceae) in southern South America, evidence from AFLP and ITS sequence data. Amer. J. Bot. 92: 352-369.

James CM, Lesemann SS, Down GJ. 2003. Modified AFLP analysis method for species with small genomes. Pl. Molec. Biol. Rep. 21: 303-307.

Kimbrough JW, Luck-Allen R, Cain RF. 1969. Iodophanus, the Pezizeae segregate of Ascophanus (Pezizales). Amer. J. Bot. 56: 1187-1202.

Kothera RT, Keinath AP, Dean RA, Farnham MW. 2003. AFLP analysis of a worldwide collection of Didymella bryoniae. Mycol. Res. 107: 297-304.

Levin L, Ramos AM, Parisi M, Gally M. 2007. Screening of Colletotrichum (Ascomycota) isolates causal agents of soybean anthracnose, for laccase production. Bol. Soc. Argent. Bot. 42: 71-77.

O'Neill NR, van Berkum P, Lin J, Kuo J, Ude GN, Kenworthy W, Saunders JA. 1997. Application of amplified fragment length polymorphism for genetic characterization of Colletotrichum pathogens of alfalfa. Phytopathology 87: 745-750.

Ramos AM, Forchiassin F, Ranalli ME, Saidman B. 2000. Isozyme analysis of different species of the genus Saccobolus (Ascomycetes, Pezizales). Mycotaxon 74: 447-462.

Roa AC, Maya MM, Duque MC, Tohme J, Allem AC, Bonierbale MW. 1997. AFLP analysis of relationships among cassava and other Manihot species. Theor. Appl. Genet. 95: 741-750.

Vos P, Hogers R, Bleeker M, Reijans M, Lee TV, Hornes M, Frijters A, Pot J, Peleman J, Kuiper M, Zabeau M. 1995. AFLP: a new technique for DNA fingerprinting. Nucl. Acids Res. 23: 4407-4414.

Zeller KA, Jurgenson JE, El-Assiuty EM, Leslie JF. 2000. Isozyme and Amplified Fragment Length Polymorphism from Cephalosporium maydis in Egypt. Phytoparasitica 28: 121-130. 
